\title{
Use of glass transition temperature for stabilization of board's cracks of Eucalyptus grandis
}

\author{
FRED W. CALONEGO ${ }^{1}$, ELIAS T.D. SEVERO ${ }^{1}$, ANTONIO R. CUNHA $^{2}$ \\ and DAIANE C. GAIA ${ }^{1}$ \\ ${ }^{1}$ Faculdade de Ciências Agronômicas, UNESP, Departamento de Recursos Naturais/Ciências Florestais \\ Fazenda Experimental Lageado, Caixa Postal 237, 18610-307 Botucatu, SP, Brasil \\ ${ }^{2}$ Faculdade de Ciências Agronômicas, UNESP, Depto de Recursos Naturais/Ciências Ambientais \\ Fazenda Experimental Lageado, Caixa Postal 237, 18610-307 Botucatu, SP, Brasil \\ Manuscript received on May 9, 2008; accepted for publication on May 17, 2010
}

\begin{abstract}
The Eucalyptus grandis logs temperatures were determined and correlated with the board's cracks during steaming. Thermocouples were inserted in the logs center, registering their temperatures during steaming at $90^{\circ} \mathrm{C}$. The logs were sawed and the board's cracks measured. It was concluded that: (1) the logistic S-shaped curve explains the logs temperature variation; (2) the logs with diameter of 20 to $<25,25$ to $<30$ and 30 to $<35 \mathrm{~cm}$ presented, respectively, $84.2^{\circ} \mathrm{C}, 73.1^{\circ} \mathrm{C}$ and $45.8^{\circ} \mathrm{C}$ in the steaming; and (3) the cracks lengths significantly decreased in logs that reached the glass transition temperature.
\end{abstract}

Key words: board's cracks, Eucalyptus grandis, glass transition temperature, logs steaming.

\section{INTRODUCTION}

Growth stresses that occur in Eucalypts wood are responsible for many defects during all the phases of wood processing and imply in yield loss. This characteristic provides problems in sawing process, drying defects and veneer split (McKenzie et al. 2003).

The origin of the growth stress is directly related to the cell walls lignifications, which are responsible for the cell walls transversal swell and cause length reduction. This reduction is avoided by the older wood cells, causing traction longitudinal stress in the stem periphery and compressing the central part (Boyd 1972, Chafe 1979, Sales 1986, Touza 2001).

One of the efficient techniques used to relief the growth stress is heating logs in water or saturated steam (Calonego and Severo 2005, Severo and Tomaselli 2000, Skolmen 1967, Tejada et al. 1997). The aim of

Correspondence to: Fred Willians Calonego

E-mail: fwcalonego@fca.unesp.br these treatments is to soften the wood in order to liberate the growth stresses (Forest Products Laboratory 1999).

Studies show $50 \%$ of reductions in the growth stress of Eucalyptus saligna logs after 24 hours of treatment in hot water (Skolmen 1967), significant reductions of $44 \%$ and $53 \%$ for the cracks length and width of Eucalyptus dunnii after steaming during 20 hours (Severo and Tomaselli 2000), and reductions of about 34\% and $48 \%$ in the cracks length and width of Eucalyptus grandis logs after 24 hours of steaming at $90^{\circ} \mathrm{C}$ (Calonego and Severo 2005).

In the evaluation of the steaming effects on drying defects of Eucalyptus grandis by submitting logs at a temperature of $90^{\circ} \mathrm{C}$ during 20 hours, it's concluded that the cracks index reduction was $18.4 \%, 27.7 \%$ and $43.4 \%$, respectively, for logs with 30 to $<35,25$ to $<30$ and 20 to $<25 \mathrm{~cm}$ of diameter (Calonego and Severo 2006). According to the authors, logs with smaller diameters present bigger reduction of defects when compared with the ones with bigger dimensions. 
The knowledge on thermal wood properties has a fundamental importance to estimate the logs steaming time (Langrish and Walker 1993).

Charts were developed to determine the heating time considering wood's thermal and physical properties, its anatomical characteristics, as well as the dimensions of the logs and desired temperature inside them, and heating bath temperature (Steinhagen et al. 1980). However, it's noted that the proposed model underestimates the real time that Eucalyptus grandis logs need to reach the desired temperature (Calonego and Severo 2006).

There is a need for specific studies about logs heating time to accurately define steaming time and temperature limits (Severo and Tomaselli 2000, Tejada et al. 1997). Yet, humidity migration and heat transference in wood are critical factors in many industrial processes of wood. But the heat and humidity transport is concerning very complex considering how heterogeneous and porous the material is.

By steaming Fagus sylvatica logs at $60^{\circ} \mathrm{C}$, it's concluded that the presence of both heartwood and sapwood in a same log does not allow an uniform stream heat in the material (Perré 2004). During the steaming, the sapwood absorbs a bigger moisture content than the heartwood does. The moisture content facilitates the heat flow and, consequently, increases the temperature, which softens the wood and shows the thermal variation differences between the two types of wood (Lenth and Haslett 2003).

The heating in saturated steam results in heating times shorter than the heating environment when filled with dry air. The temperature in the board's center of Pinus resinosa reached $56^{\circ} \mathrm{C}$ after 23 minutes during the steaming at $85^{\circ} \mathrm{C}$, and reached the same temperature after 47.8 minutes in the environment with $23.7 \%$ of relative humidity and $85^{\circ} \mathrm{C}$. (Simpson and Illman 2004).

Increases in wood temperature and moisture content are useful for physically softening the wood structure (Lenth and Kamke 2001, Romeiro de Aguiar and Perré 2005). In simple terms, the wood cell wall is a composite made of a rigid cellulose polymer in a matrix of lignin and hemicelluloses. The lignin polymer in the middle lamella and S2 layer are thermoplastic; that is, it softens upon heating (Forest Products Laboratory 1999).
Concerning heating, it is desirable to create an environment where the amorphous polymers of wood reach its glass transition temperatures and are softened, which allows internal tensions relieves by the molecular and microstructural re-organization of wood (Lenth and Haslett 2003, Nakano 2005, Romeiro de Aguiar and Perré 2005).

In saturated and heated woods there is an increase of their ductibility due to their amorphous components of viscoelastic properties (lignin and hemicelluloses), which are responsible for wood softening and its relief from growth stress levels (Calonego and Severo 2005, Forest Products Laboratory 1999, McKenzie et al. 2003).

Many authors have reported the glass transition of wood and its chemicals components under various conditions. The glass transition temperatures of the chemical components of wood differ. The softening points of about $80^{\circ} \mathrm{C}$ and $100^{\circ} \mathrm{C}$ are attributed to hemicelluloses and lignin, respectively (Hillis and Rozsa 1985). The glass transition temperature of the lignin is about $170^{\circ} \mathrm{C}$ (Forest Products Laboratory 1999). The glass transition temperature is $40^{\circ} \mathrm{C}$ for hemicelluloses, $50^{\circ} \mathrm{C}$ to $100^{\circ} \mathrm{C}$ for lignin, above $100^{\circ} \mathrm{C}$ for cellulose (Furuta et al. 1997), and around $60^{\circ} \mathrm{C}$ to $70^{\circ} \mathrm{C}$ for wood lignin (Kelley et al. 1987).

The glass transition temperature of wood is the same as the lignin, which is found to be between $60^{\circ} \mathrm{C}$ and $200^{\circ} \mathrm{C}$, and the decrease of the moisture content of wood increases the glass transition temperature (Lenth and Kamke 2001). In general, for green wood lignin, the glass transition is around $60^{\circ} \mathrm{C}$ (Nakano 2006).

For Couratari guianensis wood, with its moisture content above the fiber saturation point, the glass transition temperature is around $95^{\circ} \mathrm{C}$ (Romeiro de Aguiar and Perré 2005). For Eucalyptus grandis wood, with the same moisture content, the glass transition temperature is around $82^{\circ} \mathrm{C}$ (Quirino and Vale 2002).

The glass transition range of lignin is used to relief the residual growth stress of trees and the one resulted from the drying process (Romeiro de Aguiar and Perré 2005).

The aim of this work was to determine the temperature variation in the Eucalyptus grandis logs center during steaming, and its correlation with cracks in the sawing process. 


\section{MATERIALS AND METHODS}

\section{Material Collection}

In this study, thirty-year-old Eucalyptus grandis logs from São Paulo Forest Institute, located in Manduri, São Paulo, Brazil, were used.

Five trees were randomly selected within 2.2 ha stand. After felling, the trees were sectioned in thirty three logs with $2.9 \mathrm{~m}$ length and classified into three diameter classes ( 20 to $<25 ; 25$ to $<30 ; 30$ to $<35 \mathrm{~cm}$ ).

Two grooves were machined at a depth equal to one third of the radius of each $\log$ at $10 \mathrm{~cm}$ from the crosscut section of the logs, according to the methodology proposed by some authors (Kubler 1987, Sales 1986).

\section{Density And Moisture Content \\ MEASURE FROM LOGS}

It was taken a $5 \mathrm{~cm}$ disk between each log to determine the moisture content based on the ovendry mass of the material and its specific gravity by applying the equations 1 and 2. A balance with $0.1 \mathrm{~g}$ of accuracy and an oven at $103 \pm 2{ }^{\circ} \mathrm{C}$ were used.

$$
\begin{aligned}
& U \%=\frac{M_{U}-M_{S}}{M_{S}} \times 100 \\
& \rho=\frac{M_{S}}{V_{V}}
\end{aligned}
$$

where:

$U \%=$ moisture content based on ovendry mass, $\%$;

$M_{U}=$ wood initial mass, g;

$M_{S}=$ ovendry mass, $\mathrm{g}$;

$\rho \quad=$ specific gravity, $\mathrm{g} \mathrm{cm}^{-3}$;

$V_{V}=$ green volume, $\mathrm{cm}^{3}$.

\section{Log's Steaming and Temperature Determinations}

Logs with $2.9 \mathrm{~m}$ length were steamed during 20 hours at $90^{\circ} \mathrm{C}$ and $100 \%$ relative humidity in a dry kiln with $3.0 \times 1.6 \times 1.6 \mathrm{~m}$ of internal dimensions.

The dryer kiln has an electric heating system that allows to reach the maximum temperature of $130^{\circ} \mathrm{C}$, a humidification system by steam, an electric boiler with $30 \mathrm{kgf} \mathrm{h}^{-1}$ of capacity to produce steam, and $8 \mathrm{kgf} \mathrm{cm}^{-2}$ of work pressure.

Each log received 1 (one) thermocouple in its center to allow the monitoring of temperature with accuracy inside the logs during the steaming. For a more detailed explanation, see Figure 1A.

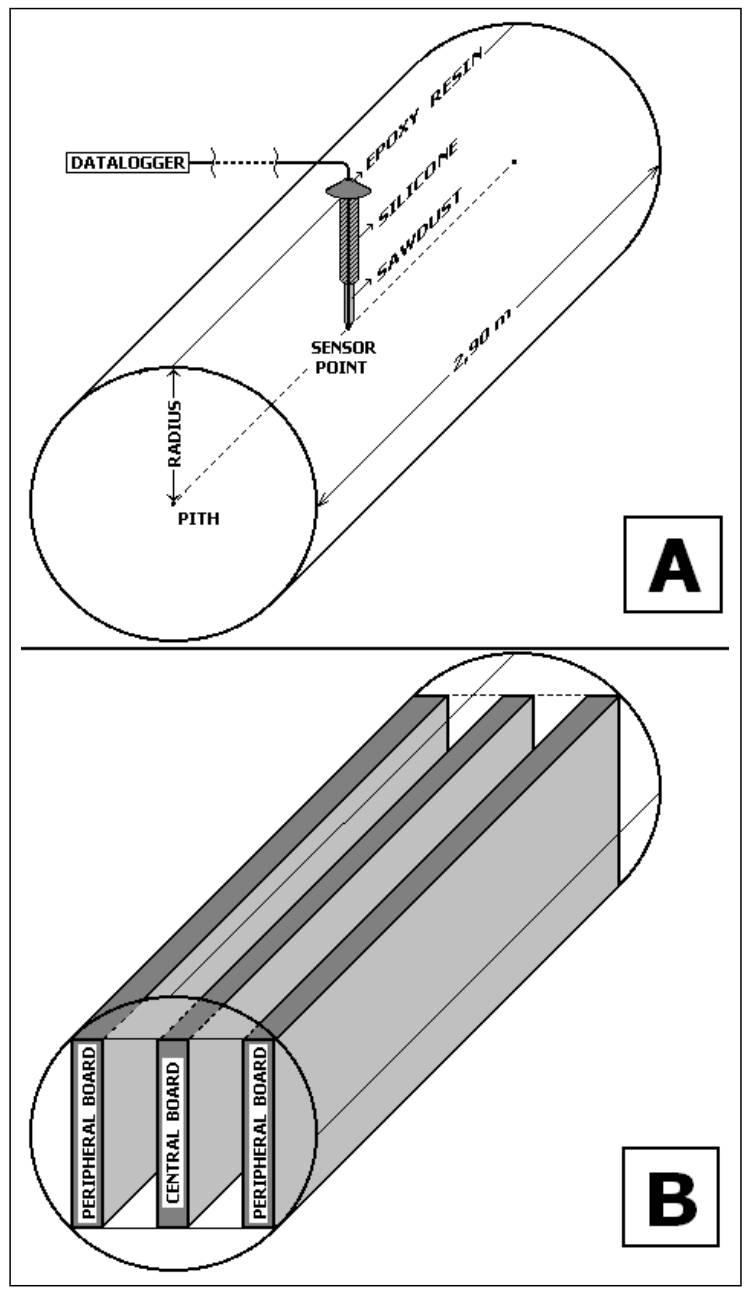

Fig. 1 - (A) Thermocouple out layers accommodation in the log; (B) peripheral and central positions of boards.

The "T-type" thermocouples $(\mathrm{Cu}-\mathrm{Co})$ were built by the union of both thermo elements using an electric founder. Subsequently, the thermocouples were submitted to gauging tests in temperatures of $0^{\circ} \mathrm{C}$ and $100^{\circ} \mathrm{C}$, which represent the points of glazing and boiling water. The values were $0.31^{\circ} \mathrm{C}$ and $97.40^{\circ} \mathrm{C}$, respectively.

Holes were carried out in the logs to perfectly accommodate the thermocouples. After fitting in the sensors, the holes were sealed with several layers: sawdust, retreat of the own hole; silicone, a resistant material to elevated temperatures and humidity conditions; thermal insulating epoxy resin; and a silicone film, which is resistant to humidity, mechanical shocks and temperature. Each material was applied with an time-out of 24 hours, to correctly dry and fix in the wood. 
The temperature range in each log diameter was monitored by the thermocouple coupled to a Campbell Scientific datalogger (Micrologger 21X) during the steaming.

\section{BOARD's CRACKS ANALYSIS}

After the steaming, the logs were sawed in flat saw boards. Initially, the logs were transformed into blocks using a twin bandsaw and, subsequently, sawed in boards with $28 \mathrm{~mm}$ thickness. As the logs were classified in diameter groups of 20 to $<25 \mathrm{~cm}, 25$ to $<30 \mathrm{~cm}$ and 30 to $<35 \mathrm{~cm}$, boards widths of $14.0 \mathrm{~cm}, 17.5 \mathrm{~cm}$ and $21.0 \mathrm{~cm}$, respectively, were obtained according to the blocks dimensions.

The flat saw boards allows to evaluate the effect of logs temperature on sawing process quality (boards cracks length) as shown by Figure 1B.

The end-cracks average lengths were evaluated and quantified through the sum of lengths of individual cracks on Eucalyptus grandis boards.

\section{RESULTS AND DISCUSSION}

The temperature behavior at each class of log diameter of E. grandis, with $0.6 \mathrm{~g} \mathrm{~cm}^{-3}$ of specific gravity and $75 \%$ of moisture content, during the steaming at $90^{\circ} \mathrm{C}$, was evaluated with accuracy.

At each minute of the 20 hours in the thermal treatment, the center logs and steam temperatures were collected according to the methodology presented in this study (see item 2.2.).

Concerning the data tendency (temperature of 11 logs per class versus time), it was applied a non-lineal model regression for each class of log diameter and for the steam temperature, as shown by Figures 2, 3 and 4.

For the steam temperature during the thermal treatment, an exponential model was chosen:

$Y=Y 0+A 1 \times\left(1-\exp \left(\frac{-X}{t 1}\right)+A 2 \times\left(1-\exp \left(\frac{-X}{t 2}\right)\right.\right.$,

where: " $Y 0$ ", " $A 1$ ", " $t 1$ ", " $A 2$ " and " $t 2$ " are the model constants; " $X$ " the logs steaming time, in hours; and " $Y$ " the steam temperature, in centigrade grade.

For the three classes of logs diameter, a logistic Sshaped curve was chosen:

$$
Y=A 2+\frac{(A 1-A 2)}{\left(1+\left(\frac{X}{X 0}\right)^{p}\right)}
$$

where: " $A 1$ ", " $A 2$ ", " $X 0$ " and " $p$ " are the model constants; " $X$ " the logs steaming time, in hours; and " $Y$ " the temperature in the logs center, in centigrade grade.

Figures 2, 3 and 4, respectively, present the adjusted model results to calculate Eucalyptus grandis logs center temperature with a diameter from 20 to $<25,25$ to $<30$ and 30 to $<35 \mathrm{~cm}$ during the first 20 hours of steaming with the temperature around $90^{\circ} \mathrm{C}$. In this case, the determination coefficients $\left(\mathrm{R}^{2}\right)$ were, respectively, $0.9885,0.9773$ and 0.9298 .

The regression model proposed for each class of Eucalyptus grandis logs diameter and its maximum temperatures achieved after 20 hours of steaming can be seen in Table I.

Through the statistical models application, it's reported that the logs centers of 20 to $<25,25$ to $<30$ and 30 to $<35 \mathrm{~cm}$ show, respectively, temperatures of $84.2^{\circ} \mathrm{C}, 73.1^{\circ} \mathrm{C}$ and $45.8^{\circ} \mathrm{C}$ in the thermal treatment end.

On the applied conditions in the present work, only Eucalyptus grandis logs with diameters from 20 to $<25 \mathrm{~cm}$ reached the glass transition temperature, which is around $82^{\circ} \mathrm{C}$ (Quirino and Vale 2002), and the glass transition range of lignin must be used to relief the residual growth stress of trees (Romeiro de Aguiar and Perré 2005).

Only logs from 20 to $<25 \mathrm{~cm}$ of diameter reached the glass transition temperature because all the three classes of log diameters were exposed on steam for 20 hours. The biggest logs hold bigger heartwood than the smallest ones. The sapwood has a bigger moisture content than the heartwood has, and the moisture content facilitates the heat flow and, consequently, increases the wood temperature and softening (Lenth and Haslett 2003).

Table II shows that logs from 20 to $<25 \mathrm{~cm}$ of diameter presented a better growth stress relief, showed by the cracks lengths in the central $(29.3 \mathrm{~cm})$ and peripheral boards $(37.3 \mathrm{~cm})$, and considered statistically equal. This result was expected; thus, the wood internal stress relieve is directly related to the material being softened (Forest Products Laboratory 1999, Romeiro de Aguiar and Perré 2005). This is characterized by lignin glass transition temperature (Lenth and Kamke 2001, Nakano 2005, Romeiro de Aguiar and Perré 2005), which is found between $50^{\circ} \mathrm{C}$ and $100^{\circ} \mathrm{C}$ (Furuta et al. 1997). 


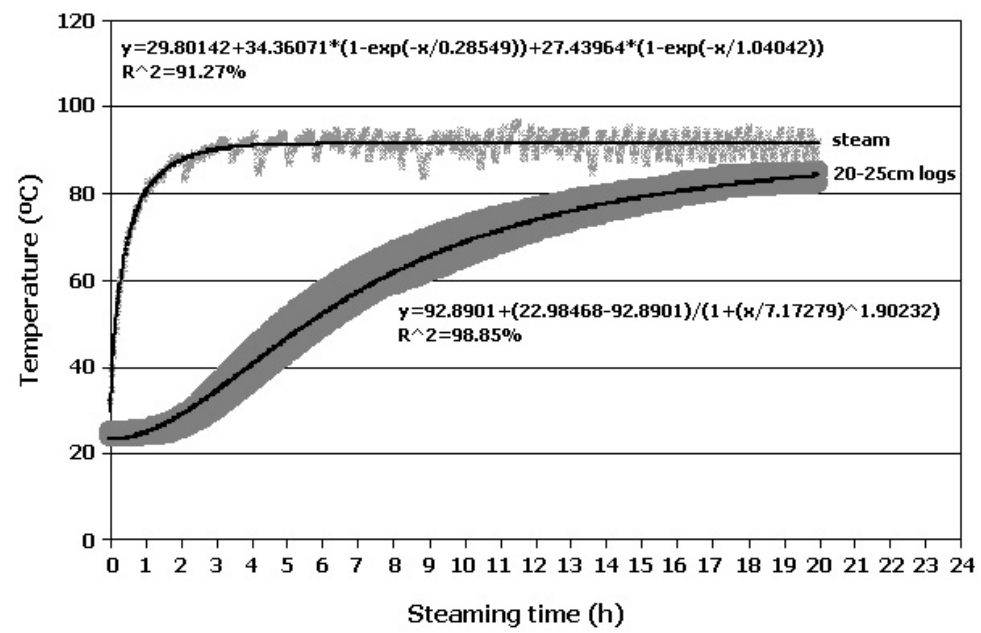

Fig. 2 - Logistics S-shaped curve adjusted for the temperature in the Eucalyptus grandis logs center classified between 20 and $<25 \mathrm{~cm}$ diameter during steaming.

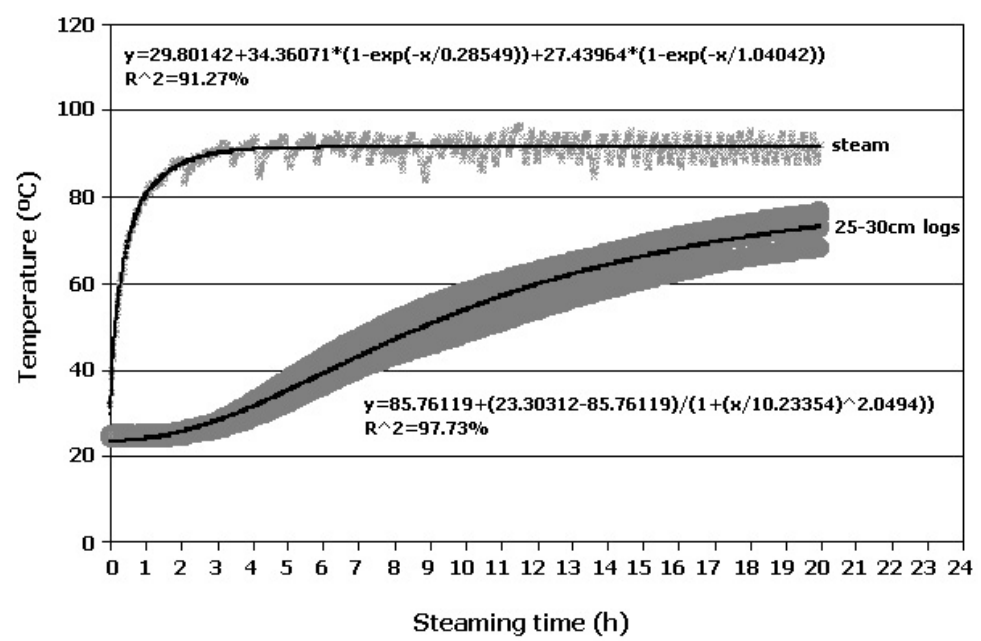

Fig. 3 - Logistics S-shaped curve adjusted for the temperature in the Eucalyptus grandis logs center classified between 25 and $<30 \mathrm{~cm}$ diameter during steaming.

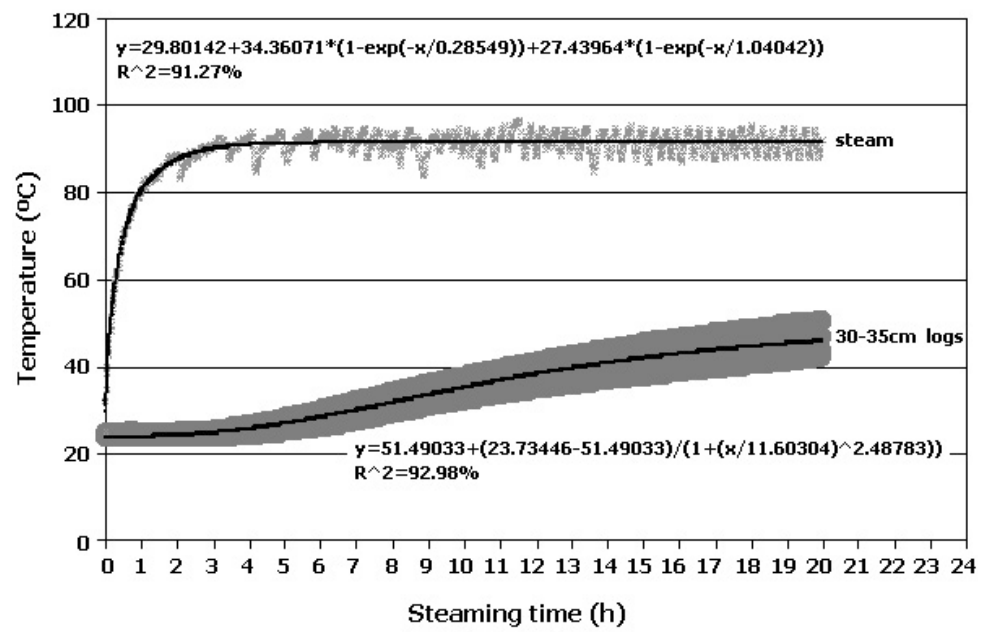

Fig. 4 - Logistics S-shaped curve adjusted for the temperature in the Eucalyptus grandis logs center classified between 30 and $<35 \mathrm{~cm}$ diameter during steaming. 
TABLE I

Proposed equations for the temperature behavior in Eucalyptus grandis logs center during steaming.

\begin{tabular}{c|c|c}
\hline $\begin{array}{c}\text { Diameter } \\
\text { classes } \\
(\mathrm{cm})\end{array}$ & \multicolumn{1}{c}{\begin{tabular}{c} 
Temperature variation in logs center \\
\hline 20 to $<25$
\end{tabular}} & $\begin{array}{c}\text { Maximum } \\
\text { temperature } \\
\left({ }^{\circ} \mathrm{C}\right)\end{array}$ \\
\hline 25 to $<30$ & $Y=85.76119+(23.30312-85.76119) /\left(1+(X / 10.23354)^{2.0494}\right)$ & 73.1 \\
\hline 30 to $<35$ & $Y=51.49033+(23.73446-51.49033) /\left(1+(X / 11.60304)^{2.48783}\right)$ & 45.8 \\
\hline
\end{tabular}

Where: "A1", "A2", "X0" and "p" - model constant; "X" - steaming time, in hours; and "Y"- logs center temperature, in ${ }^{\circ} \mathrm{C}$.

TABLE II

End-cracks average length variation in center and peripheral boards after sawing steamed logs of Eucalyptus grandis.

\begin{tabular}{c|c|c|c|c|c|c}
\hline \multirow{2}{*}{ Board } & \multicolumn{2}{|c|}{ Logs 30 at $<35$} & \multicolumn{2}{c|}{ Logs 25 at $<30$} & \multicolumn{2}{c}{ Logs 20 at $<25$} \\
\cline { 2 - 7 } & $\mathrm{N}$ & $\begin{array}{c}\text { End-cracks } \\
(\mathrm{cm})\end{array}$ & $\mathrm{N}$ & $\begin{array}{c}\text { End-cracks } \\
(\mathrm{cm})\end{array}$ & $\mathrm{N}$ & $\begin{array}{c}\text { End-cracks } \\
(\mathrm{cm})\end{array}$ \\
\hline Peripheral & 11 & 58.6 & 11 & 42.5 & 11 & 29.3 \\
\hline Central & 11 & 88.8 & 11 & 60.7 & 11 & 37.3 \\
\hline $\begin{array}{c}\text { Increase of } \\
\text { defect }\end{array}$ & \multicolumn{2}{|c|}{$51.54 \%^{*}$} & \multicolumn{2}{|c|}{$42.82 \%^{\mathrm{NS}}$} & \multicolumn{2}{|c}{$27,31 \% \mathrm{NS}$} \\
\hline
\end{tabular}

Where: ${ }^{*}$ - there is a significant difference of $95 \%$ of probability by the $\mathrm{F}$ test; $\mathrm{NS}$ - there is no significant difference; $\mathrm{N}$ - repeated number.

The logs with diameters from 30 to $<35 \mathrm{~cm}$ presented cracks lengths statistically different in peripheral and central boards, and it was concomitant with the diameter class in which the logs did not reach the necessary temperature to cause the molecular and microstructural re-organization of wood. This is responsible for the internal tensions relief, according to the same authors (Lenth and Haslett 2003, Lenth and Kamke 2001, Nakano 2005, Romeiro de Aguiar and Perré 2005).

Concerning wood quality, Table II shows that there is a straight relationship between the boards cracks length and the steamed logs diameter. Similar results were obtained by another author (Calonego and Severo 2004) by studying the steaming effects on drying defects in Eucalyptus grandis logs, they concluded that the cracks reduction was $18.4 \%, 27.7 \%$ and $43.4 \%$, respectively, for boards with diameters from 30 to $<35$, 25 to $<30$ and 20 to $<25 \mathrm{~cm}$. This study also showed that logs with smaller diameters presented minors defects when compared with logs of bigger dimensions that were steamed in the same conditions.

Reporting the logs temperatures of Eucalyptus grandis during 20 hours of steaming at $90^{\circ} \mathrm{C}$ led us to the following conclusions: (1) the logistic S-shaped curve is applicable to explain the temperature variation in the logs center; (2) the cracks lengths were significantly decreased in logs that reached the glass transition temperature.

These results could allow the use of steaming optimum time and avoid wasting energy. The models are appropriate for the studied conditions (temperature, time and procedures). However, data simulations may increase the charts range in future studies.

\section{ACKNOWLEDGMENTS}

The authors thank the Fundação de Amparo à Pesquisa do Estado de São Paulo (FAPESP), Brazil, for financial support to conduct this research work through grants 02/05028-6 and 00/02165-7.

\section{RESUMO}

As temperaturas em toras de Eucalyptus grandis, durante a vaporização, foram determinadas e correlacionadas com as rachaduras das tábuas. Nos centros das toras foram inseridos termopares e registradas suas temperaturas durante a vaporização à $90^{\circ} \mathrm{C}$. As toras foram desdobradas e as rachaduras das tábuas mensuradas. Concluiu-se que: (1) o modelo estatístico sigmoidal logístico explica a variação da temperatura nas 
toras; (2) as toras com 20 a $<25,25$ a $<30$ e 30 a $<35 \mathrm{~cm}$ de diâmetro apresentaram, respectivamente, $84,2^{\circ} \mathrm{C}, 73,1^{\circ} \mathrm{C}$ e $45,8^{\circ} \mathrm{C}$ ao final da vaporização; e (3) as rachaduras foram significativamente menores nas toras que atingiram a temperatura de transição vítrea.

Palavras-chave: rachaduras de tábua, Eucalyptus grandis, temperatura de transição vítrea, vaporização de toras.

\section{REFERENCES}

BOYD JD. 1972. The growth stresses: evidence of a origin in differentiation and lignification. Wood Sci Technol 6: 251-262.

Calonego FW and Severo ETD. 2004. Efeito da vaporização de toras na secagem da madeira de Eucalyptus grandis. Fl Amb 11(1): 07-13.

Calonego FW And Severo ETD. 2005. Efeito da vaporização de toras na redução dos defeitos associados a tensões de crescimento de Eucalyptus grandis. Ci Fl15(4): 431-440.

Calonego FW and Severo ETD. 2006. Estimativa do tempo de vaporização de toras de Eucalyptus grandis. Rev Arvore 30(3): 457-462.

Chafe SC. 1979. Growth stresses in trees. Australian For Res 9(3): 203-223.

FOREST PRODUCTS LABORATORY. 1999. Wood handbook: wood as an engineering material, Washington: US department of agriculture, $463 \mathrm{p}$.

Furuta Y, Aizawa H, Yano H And Norimoto M. 1997. Thermal-softening properties of water-swollen wood: IV. Effects of chemical constituents of the cell wall on the thermal-softening properties of wood. Mokuzai Gakkaishi 43(9): 725-730.

Hillis WE AND RozSA AN. 1985. High temperature and chemical effects on wood stability: the effect of heat on the softening of radiate pine. Wood Sci Technol 19: $57-66$.

Kelley SS, Timothy GR AND Glasser WG. 1987. Relaxation behaviour of the amorphous components of wood. J Mater Sci 22: 617-624.

KUBLER H. 1987. Growth stresses in trees and related wood properties. Forest Prod Abstr 10(3): 61-119.

LANGRISH TAG AND WALKER JCF. 1993. Transport process in wood. In: WALKer JCF ET AL., Primary wood processing: principles and practice. London: Chapman \& Hall, p. 121-152.

LENTH CA AND HASLETT AN. 2003. Moisture uptake patterns in pressure steaming of Radiata Pine. Holz Roh Werkst 61(6): 444-448.
Lenth CA AND Kamke FA. 2001. Moisture dependent softening behavior of wood. Wood Fiber Sci 33(3): 492507.

MCKenzie HM, Turner JCP AND Shelbourne CJA. 2003. Processing young plantation-grown Eucalyptus nitens for solid-wood products. 1: Individual-tree variation in quality and recovery of appearance-grade lumber and veneer. NZ J For Sci 33: 62-78.

NAKANO T. 2005. Effects of quenching on relaxation of wet wood. J Wood Sci 51(2): 112-117.

NAKANO T. 2006. Analysis of the temperature dependence of water sorption for wood on the basis of dual mode theory. J Wood Sci 52(6): 490-495.

PERRÉ P. 2004. Electrical heating of green logs using Joule's effect: a comprehensive computational model used to find a suitable electrode design. Wood Sci Technol 38(6): 429-449.

QUIRINO WF AND VALE AT. 2002. Retificação térmica de Eucalyptus grandis. In: CONGRESSO IBERO-AMERICAno de Pesquisa e Desenvolvimento de ProduTOS Florestais, Curitiba, Proceedings, Curitiba, $10 \mathrm{p}$.

Romeiro de Aguiar OJ ANd Perré P. 2005. Wood accelerating drying process based on its rheological properties. United States Patent, US n. 006910284B2.

SALES CG. 1986. Growth stresses: main results obtained on the study of guyana species and consequences for and use. In: IUFRO World Congress, 18, Ljubljana. Proceedings, Ljubljana: IUFRO, p. 234-248.

Severo ETD AND Tomaselli I. 2000. Efeito da vaporização no alívio das tensões de crescimento em toras de duas procedências de Eucalyptus dunnii. Sci Agr 1(1-2): 29-32.

SIMPSON WT AND ILLMAN BL. 2004. Heat sterification times of red pine boards. Forest Prod J 54(12): 240-244.

Skolmen RG. 1967. Heating Logs To Relieve Growth Stresses. Forest Prod J 17: 41-42.

Steinhagen HP, Meyers GE AND Kubler H. 1980. Heating times charts for frozen and nonfrozen veneer logs. Forest Prod J 30(4): 27-37.

Tejada A, OKuyama T, Yamamoto H and Yoshida M. 1997. Reduction of growth stress in logs by direct heat treatment: assessment of a commercial-scale operation. Forest Prod J 47(9): 86-93.

TouzA MC. 2001. Proyecto de investigación sobre sistemas de aserrado adecuados para procesar Eucalyptus globulus con tensiones de crecimiento. Revista CISMadera 6: $8-37$. 